\title{
27. STRUCTURAL FEATURES AT THE DEHURMATION FRONT OF THE BARBADOS RIDGE COMPLEX, DEEP SEA DRILLING PROJECT LEG 78A ${ }^{1}$
}

\author{
Darrel S. Cowan, Department of Geological Sciences, University of Washington \\ and
}

J. Casey Moore, Sarah M. Roeske, Neil Lundberg, and Stephen E. Lucas, Earth Sciences and Marine Studies, University of California at Santa $\mathrm{Cruz}^{2}$

\begin{abstract}
Mesoscopic structural features observed in cores from Sites 541 and 542 are associated with biostratigraphically defined faults. At Site 541, a fault at $262 \mathrm{~m}$ occurs within an interval characterized by probable stratal disruption and randomly oriented, semipenetrative, slickensided slip surfaces. Disrupted Miocene hemipelagic mud was emplaced over Pliocene nannofossiliferous mud along a sharply defined reverse fault visible at $276 \mathrm{~m}$. Thin sections and SEM photomicrographs show that platy clay minerals in the penetratively deformed, smectite-rich Miocene mud acquired a strong planar preferred orientation. The lower $70 \mathrm{~m}$ of core from Site 541 is disrupted, characterized locally by a scaly foliation, with more lithified tectonic inclusions of variably colored radiolarian mudstone. These deformed Miocene radiolarian muds were sampled from a major seismically defined subhorizontal décollement. Slickensided surfaces and probable stratal disruption in the lower part of Hole 542A are probably associated with a subhorizontal thrust zone immediately above the main décollement.
\end{abstract}

\section{INTRODUCTION}

Deep-sea drilling at modern convergent plate boundaries offers an unparalleled opportunity to sample the structural features that develop in accreted sediments. Results from active margins can be used to interpret structures in ancient subduction complexes on land and to test tectonic models of subduction, such as the popular imbricate-thrust hypothesis of Karig (1974), Seely et al. (1974), and others.

Leg 78A was a short, three-hole transect drilled across the seaward edge of the Barbados Ridge complex (Fig. 1), which constitutes part of the forearc region of the Lesser Antilles intraoceanic volcanic arc. Drilling at Sites 541 and 542 penetrated at least five thrust faults along which hemipelagic sediments had been imbricated as they were scraped off the descending oceanic plate. In addition, drilling at Site $\mathbf{5 4 1}$ may have passed through a seismically defined décollement zone along which sediments and underlying oceanic crust are selectively thrust beneath the overlying, internally imbricated accretionary wedge. The purpose of this chapter is to document the mesoscopic and microscopic fabrics associated with these major structures. Cowan and Moore studied mesoscopic features in freshly cut cores on board the Challenger during the leg. The graphic structural log (Fig. 2) was compiled from their observations and those of Lundberg, who reexamined all Leg 78A cores onshore. This log shows the orientation of bedding and the distribution of mesoscopic structures in cores from Sites 541 and 542. At the University of Washington and University of

\footnotetext{
${ }^{1}$ Biju-Duval, B., Moore, J. C., et al., Init. Repts. DSDP, 78A: Washington (U.S. Govt. Printing Office).

2 Address: (Cowan) Department of Geological Studies, University of Washington, Seattle, WA 98195; (Moore, Roeske, and Lucas) Earth Sciences and Marine Studies, University of California at Santa Cruz, Santa Cruz, CA 95064; (Lundberg, present address) Dept. of Geological and Geophysical Sciences, Princeton University, Princeton, N.J. 08540.
}

California, using a variety of impregnation techniques, we prepared thin sections from samples of both deformed and undeformed hemipelagic muds. S. Roeske and S. Lucas obtained and interpreted the scanning electron microscope (SEM) photomicrographs illustrating details of the microfabrics.

\section{HOLE 541}

The most important mesoscopic structures observed in cores from this hole were (1) a thrust fault in Core 30 , along which green Miocene hemipelagic mud was emplaced above light gray Pliocene nannofossiliferous mud, and (2) a shear zone, in the lower $75 \mathrm{~m}$ of core, consisting predominantly of penetratively deformed, foliated, scaly mud. Stratal disruption was noted in both the 25 $\mathrm{m}$ of mud immediately above the thrust and within the shear zone. The thrust in Core 30 is one of three olderover-younger faults at Hole 541 that can be defined on the basis of repeated biostratigraphic zones, but it is the only fault that is clearly visible in the cores because it separates differently colored lithologic units. None of the three faults is unequivocally resolved on seismic reflection profiles (see Ngokwey et al., this volume). The foliated muds encountered near the bottom of Hole 541 represent the upper part of an extensive décollement within Miocene pelagic strata. This décollement is visible on seismic lines within the Leg 78A area and elsewhere beneath the Barbados Ridge complex (Ngokwey et al., this volume; Westbrook et al., this volume). On one seismic line just north of the Leg 78A area, the décollement can be traced $80 \mathrm{~km}$ arcward of the deformation front (Westbrook et al., this volume).

\section{Orientation of Bedding}

True dips, measured on ash layers and bedding surfaces in hemipelagic muds, are plotted on the graphic structural log (Fig. 2). Layers are horizontal to a sub- 


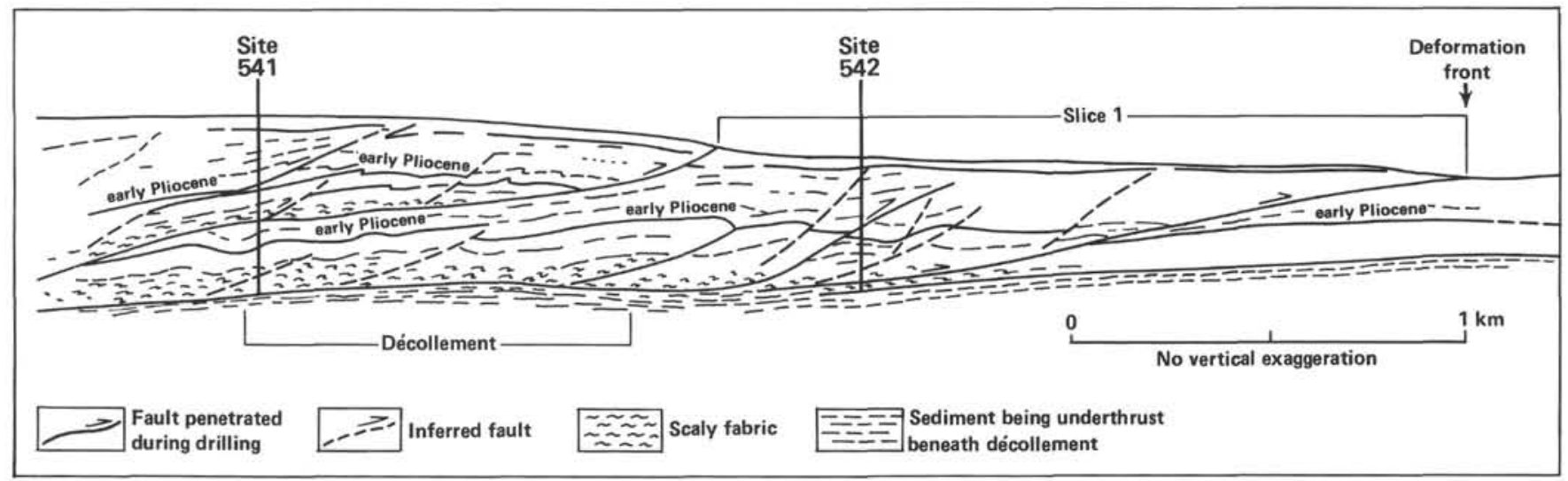

Figure 1. Composite interpretive cross-section through Sites 541 and 542 and across the deformation front of the Barbados Ridge complex, incorporating both drilling results from $\mathrm{Leg} 78 \mathrm{~A}$ and data from reflection profiles.
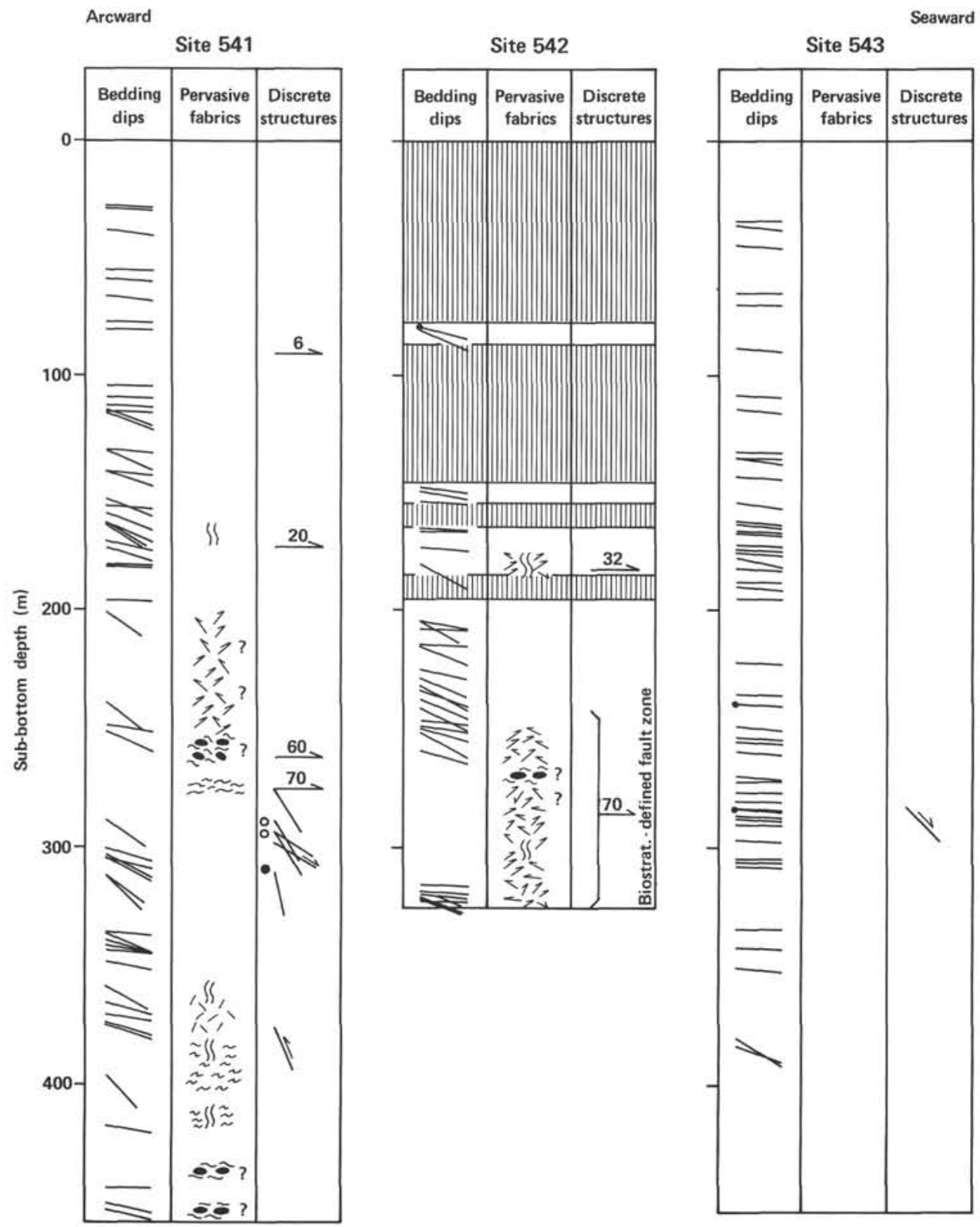

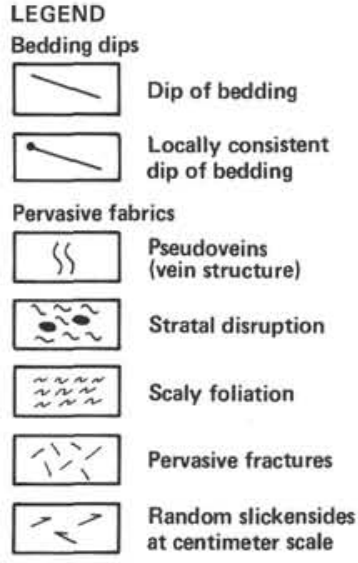

Discrete structures

Oiscrete inclined fracture

Lengths of affected intervals somewhat exaggerated for portrayal of features

Figure 2. Graphic structural log from Leg 78A sites. 
bottom depth of $116 \mathrm{~m}$. From this point to the onset of semipenetrative internal disruption at about $200 \mathrm{~m}$, alternating sections of mud 5 to $20 \mathrm{~m}$ thick are characterized by either horizontal layers or layers dipping 20 to $40^{\circ}$. The more steeply dipping intervals may reflect gentle tilting or folding produced during displacements along small faults or décollements within soft Pliocene muds, but no lithologic or biostratigraphic changes were observed to correlate with changes in dip, nor were any complete folds observed in the cores. The dipping intervals might alternatively represent small gravity-driven slumps.

\section{Thrust Faults}

\section{Mesoscopic Characteristics}

The conspicuous thrust fault of $276 \mathrm{~m}$ in Hole 541 is structurally overlain by a deformed zone including another, lithologically less dramatic fault at $262 \mathrm{~m}$. The total throw on these faults is about $130 \mathrm{~m}$, partitioned approximately equally between the two structures. The fault at $276 \mathrm{~m}$ Sample 541-30-6, 122-143 cm) emplaces green upper Miocene mud over light gray nannofossilrich, middle Pliocene mud (Fig. 3). The actual fault surface has been truncated and reoriented by rotations along horizontal drilling laminations, so its dip in situ could not be determined. There is little intermixing of the two lithologic units along the fault, but the contact is locally irregular and contorted, probably because displacements along it occurred while the muds were soft and pliant. The folding of the fault surface may in part reflect effects of drilling, aithough this deformation predated the formation of drilling laminations that cut the folded fault. Petrographic study showed that the 1 to 5 $\mathrm{mm}$ black zone parallel to the lithologic contact is apparently the result of staining or submicroscopic coatings on mineral grains rather than a cataclastic diminution in grain size.

Semipenetrative deformation of the Miocene hemipelagic mud is evident for about $60 \mathrm{~m}$ above the fault at $276 \mathrm{~m}$ (Fig. 2). The fault at $262 \mathrm{~m}$ apparently is represented by a zone of stratal disruption in Core 541-29, Section 3,140 cm. A few 10-cm-thick intervals in Cores 23 and 24 , most of Cores 25 to 29 , and most of Core 30 above the fault are pervaded by polished and striated surfaces that can be broken out of drilling biscuits on a scale of $1 \mathrm{~cm}$ or so (Fig. 4). They are numerous, of diverse orientations, and are interpreted as slip surfaces that accommodated and distributed small (less than millimeter-scale) displacements through the pliant mud. As a result of this mesoscopic flow, bioturbation structures have been typically obliterated, and layers of distinctly colored mud have been broken up, disharmonically swirled, and generally disrupted. Consequently, few dips could be measured in this disrupted section in comparison to internally undeformed muds above and below (Fig. 2). The slip surfaces are more penetrative in the section about $20 \mathrm{~cm}$ above the fault at $276 \mathrm{~m}$ (Core 30, Section 6) where they impart a scaly foliation to the mud. An isolated 7-cm-long fault, dipping $60^{\circ}$, with striations pitching $80^{\circ}$ on its polished surface, occurs in Core 25 ,

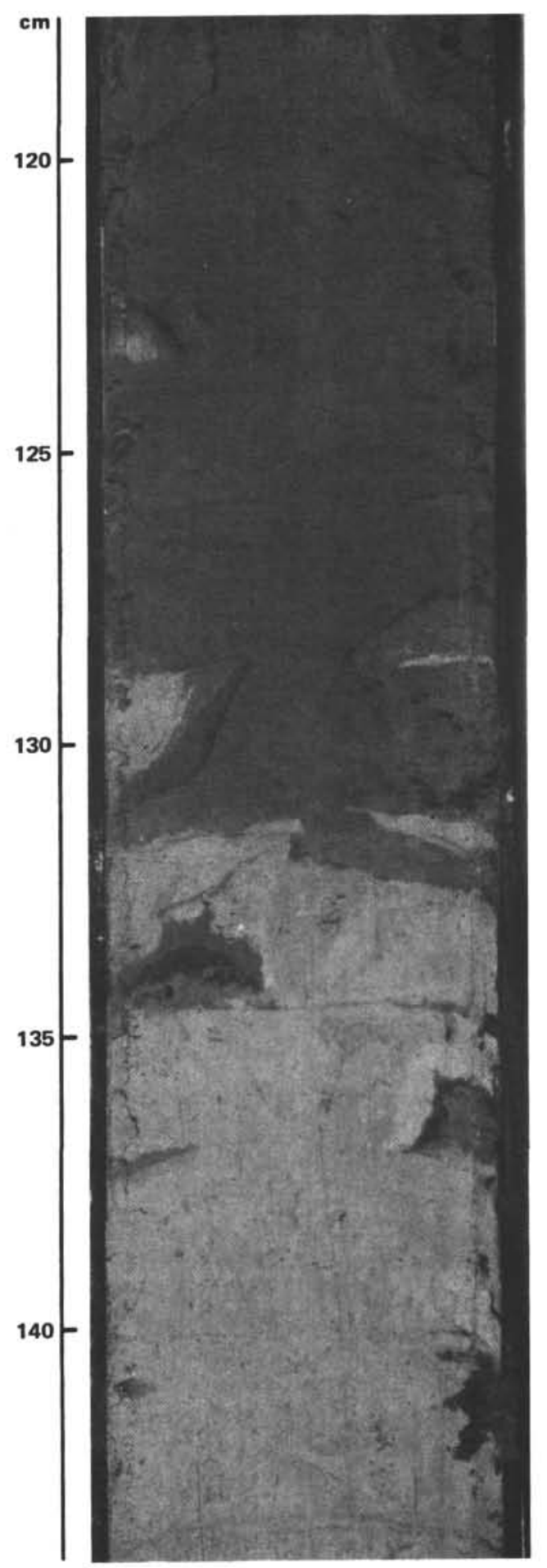

Figure 3. Sample 541-30-6, 117-144 cm, illustrating a thrust fault emplacing Miocene hemipelagic mud (dark gray) over Pliocene nannofossil and foraminifer-rich calcareous mud (light gray). (The fault surface, which is sharp but irregular, has been offset and rotated on horizontal drilling fractures.)

Section 5. The distributed deformation in Cores 25 to 30 is interpreted to be related to the thrust faults at 262 and $276 \mathrm{~m}$, and it may have been fostered by the increased percentage of smectite in this interval (Pudsey, this volume). The original geometry of the complex stratal disruption is obscure because of subsequent drilling-in- 


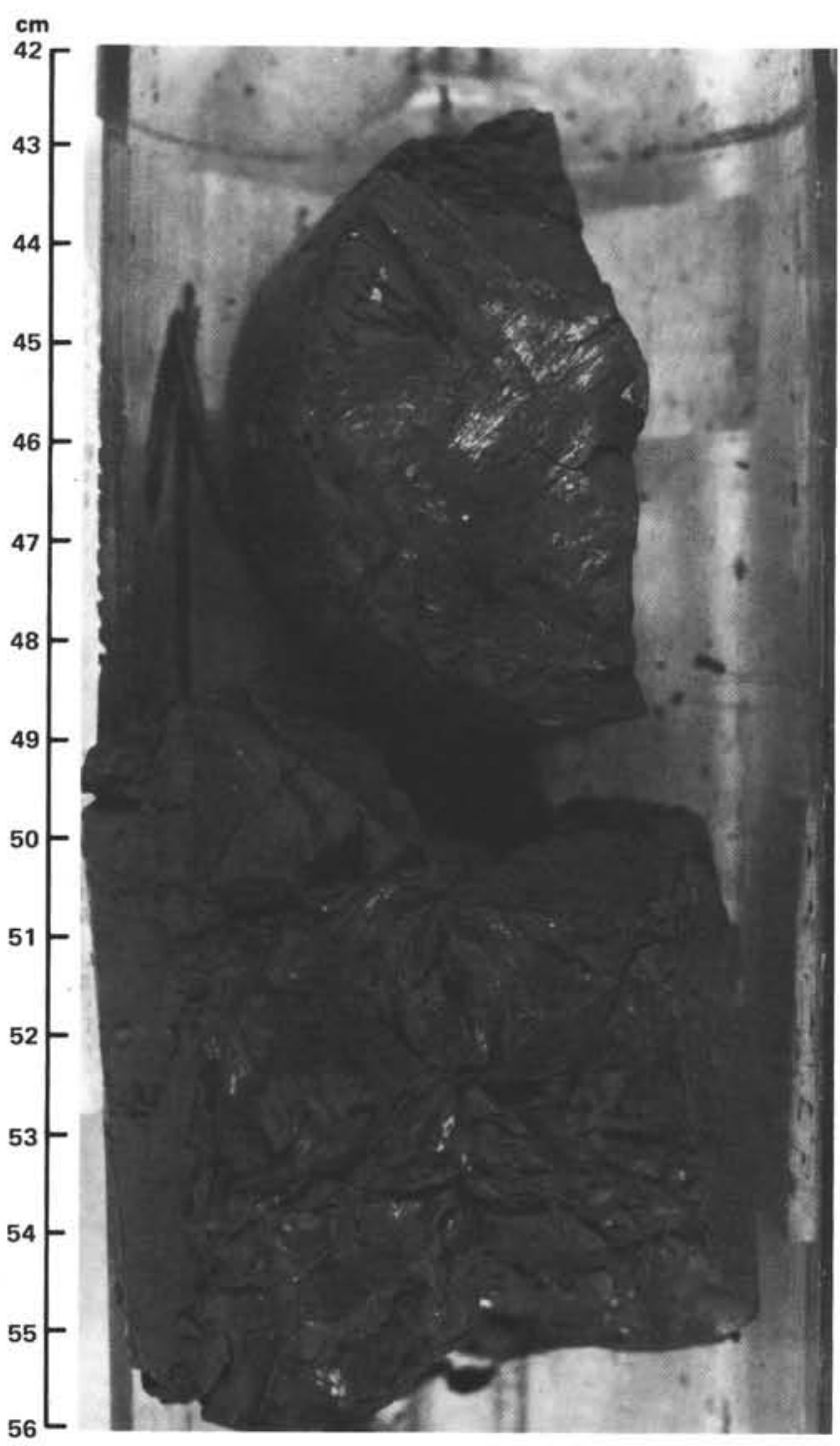

Figure 4. Photograph of the interior of the core-catcher from Site 541, Core 25. (Diversely oriented, polished and striated, mesoscopic slip surfaces are distributed throughout the mud.)

duced rotations. The degree to which these structures were enhanced by drilling is arguable. However, evidence of a fundamental tectonic origin includes the general lack of similarly intense deformation in smectitic clays removed from biostratigraphically defined faults.

In contrast to the Miocene sediments, the Pliocene mud below the fault has little mesocopic evidence of deformation. There are a few centimeter-scale diversely oriented polished surfaces and a single steeply dipping fault in the first section of core below the fault. In Section 541-32 a fault dipping $50^{\circ}$ has striations pitching 64 to $75^{\circ}$. In contrast to other Hole 541 sequences, discrete faults are concentrated in the $40 \mathrm{~m}$ of carbonate-rich sediment immediately below $276 \mathrm{~m}$. In general, bedding surfaces are well-preserved, and the sediments in Cores 31 to 41 dip an average of $25^{\circ}$ but can go as high as $45^{\circ}$ (Fig. 2).

\section{Microfabric}

Thin sections containing the fault surface at $276 \mathrm{~m}$ were prepared from samples obtained from Section 54130-6 (photographed in Fig. 3). The curvilinear (in section) contact is locally sharp, but some mixing of Miocene hemipelagic mud and Pliocene foraminifer-rich nannofossiliferous mud occurs in a zone $0.3 \mathrm{~mm}$ wide. Under crossed nicols, the Miocene sediment is characterized by both (1) irregular, patchy domains in which clay minerals have a planar preferred orientation, and (2) subparallel, narrow to locally braided zones in which the platy minerals are strongly oriented parallel to the boundaries of the zone (Fig. 5). These zones are interpreted to be microscale surfaces and zones of slip. A network of morphologically similar, but randomly oriented, zones ( $0.4 \mathrm{~mm}$ and less in width) was observed in Miocene mud from Core 25 , about $45 \mathrm{~m}$ above the fault. In this interval, some of these zones are apparently expressed mesoscopically as diversely oriented, semipenetrative polished surfaces (Fig. 4). In contrast, the Pliocene calcareous sediment generally has a random fabric, even adjacent to the fault surface (Fig. 5). The different mineralogy of these two sediments influenced their behavior during deformation; penetrative slip on the microscopic scale was facilitated by the high proportion of clay minerals, relative to carbonate, in the Miocene hemipelagic mud.

SEM photomicrographs show that the fabrics of the Miocene and Pliocene muds are different even at submicroscopic scales. Figure 6 illustrates the fault at $276 \mathrm{~m}$ separating the differing lithologic units in Section 541$30-6$. The contact is sharp at this scale, with the green hemipelagic Miocene mud having a smooth, "plastered" texture imparted by the strong preferred orientation of clay particles (Fig. 7). In the calcareous Pliocene mud adjacent to the fault surface, a planar fabric is weakly developed or absent (Fig. 6). The strong planar fabric in Miocene mud resulted from penetrative deformation probably related to slip along the thrust fault. Samples of the same stratigraphic unit from Site 543, on Atlantic oceanic crust east of the deformation front drilled at Site 541, illustrate the microfabric of undeformed muds that have yet to become involved in offscraping and accretion. In comparison to samples from the deformed sediments at Site 541, they have a much weaker planar fabric defined by the preferred orientation of some clay particles parallel to bedding (Fig. 8A and $\mathrm{B})$.

\section{Décollement Zone}

\section{Mesoscopic Characteristics}

The thrust fault described in the previous section is underlain by about $85 \mathrm{~m}$ of gently to moderately dipping but otherwise undeformed sediments. In Cores $541-40,-41$, and -42 , coherent mudstone in "drilling biscuits" (short cylinders of mudstone separated by horizontal, drilling-induced, rotational fractures) is fractured and locally brecciated. The intensity of fracturing 


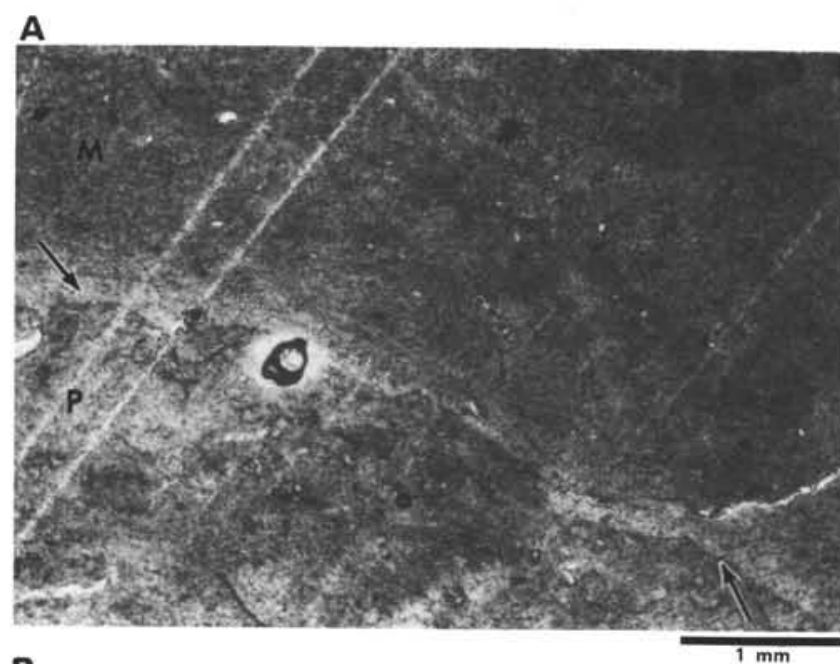

B
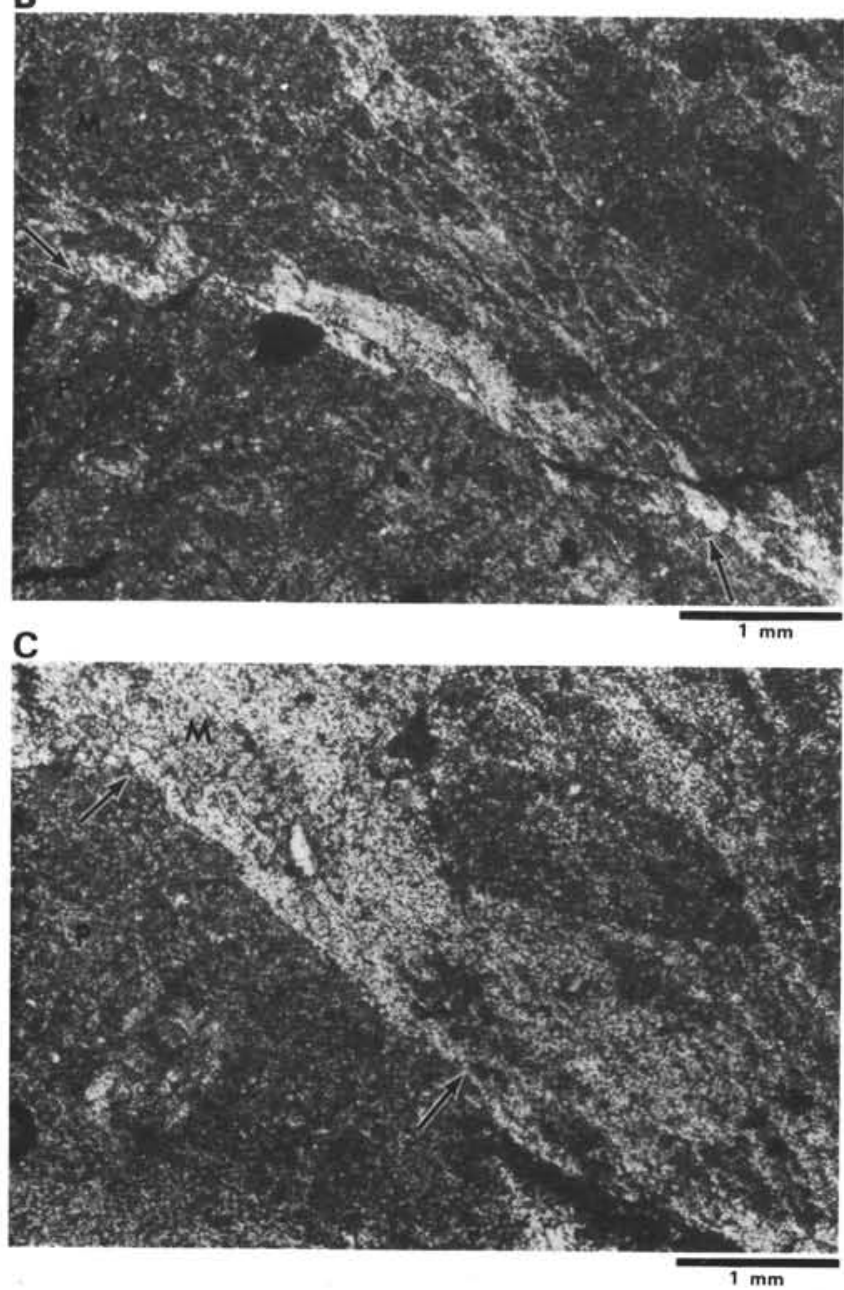

Figure 5. A-C. Photomicrographs of the fault surface in a sample collected from Core 541-30, Section 6. (The sharp contact between Miocene (M) and Pliocene (P) muds is denoted by the arrows. A. Plane light; B and C. Crossed nicols. Phyllosilicates in the clayrich Miocene mud have a strong planar preferred orientation adjacent to the contact and in narrow zones subparallel to it. Oriented platy minerals are bright when viewed at $45^{\circ}$ off extinction, as in B and C. Calcareous Pliocene mud appears devoid of a fabric at this scale.) is variable, and fractures are apparently randomly disposed. The fine preservation of bioturbation structures suggests that displacements along the fractures were negligible.

From Core 42, Section 5 to the bottom of the hole (387-459 m sub-bottom), penetratively deformed, foliated scaly mudstone is abundant. It occurs in 10- to 20$\mathrm{cm}$-thick zones separating intervals of stiff, but fractured, bioturbated mudstone. Locally, deformation was so intense that stiff mudstone was converted into soft, pliant, clayey gouge. Some scaly zones are as much as 1 $\mathrm{m}$ thick. Samples of scaly mudstone have a flaky texture and can be disaggregated into innumerable small, polished lenticular chips. The polished surfaces have a strong planar preferred orientation that defines a predominantly horizontal foliation (Fig. 9). The orientation of the foliation is locally variable, however, due to rotation of individual biscuits during drilling. A distinctive feature of the scaly zones is the presence of lensshaped inclusions or wispy streaks of mudstone and ash that are colored differently and are more coherent than the surrounding scaly matrix. These inclusions record modest stratal disruption and mixing in the shear zone. Only a few undisturbed bedding surfaces or beds were observed in the deformed interval below Core 42 (see Fig. 2).

The scaly foliation is interpreted as the mesoscopic expression of displacements along innumerable subparallel slip surfaces. In terms of mesoscopic fabric these foliated mudstones strongly resemble brittlely deformed (or "sheared") mudstones and serpentinites in on-land fault zones. In view of the independent evidence, on seismic reflection profiles, of a major décollement at approximately this depth at Site 541 , drilling probably penetrated the top $75 \mathrm{~m}$ or so of this major shear zone and possibly $20 \mathrm{~m}$ into the lower underthrust acoustically layered sequence. Distributed brittle deformation, which was localized at the lithologic change from hemipelagic mud to underlying radiolarian-rich pelagic clay, may have been fostered by high fluid pressures, in view of the independent evidence for elevated pressures provided when the hole was packed off during drilling (see Site 542 report, this volume).

\section{Microfabric}

In thin section (Fig. 10), scaly mudstone consists of lenticular domains of randomly to strongly oriented platy phyllosilicates, and subparallel curvilinear zones, 0.05 to $1 \mathrm{~mm}$ wide, in which the phyllosilicates are strongly oriented parallel to the boundaries of the zone. This microfabric resembles that in the deformed Miocene muds in Cores 541-25 to 30 above the thrust fault.

An SEM photomicrograph (Fig. 11) illustrates the moderate preferred orientation of platy phyllosilicates. In detail, the foliation is locally undulatory, and smooth, "plastered" surfaces are reminiscent of the features observed in SEM photomicrographs of deformed muds above the thrust (Fig. 6). The preferred orientation in phyllosilicates on the scale of individual clay particles is ascribed to penetrative slip. Submicroscopic brittle deformation seems also to have affected radiolarians in 


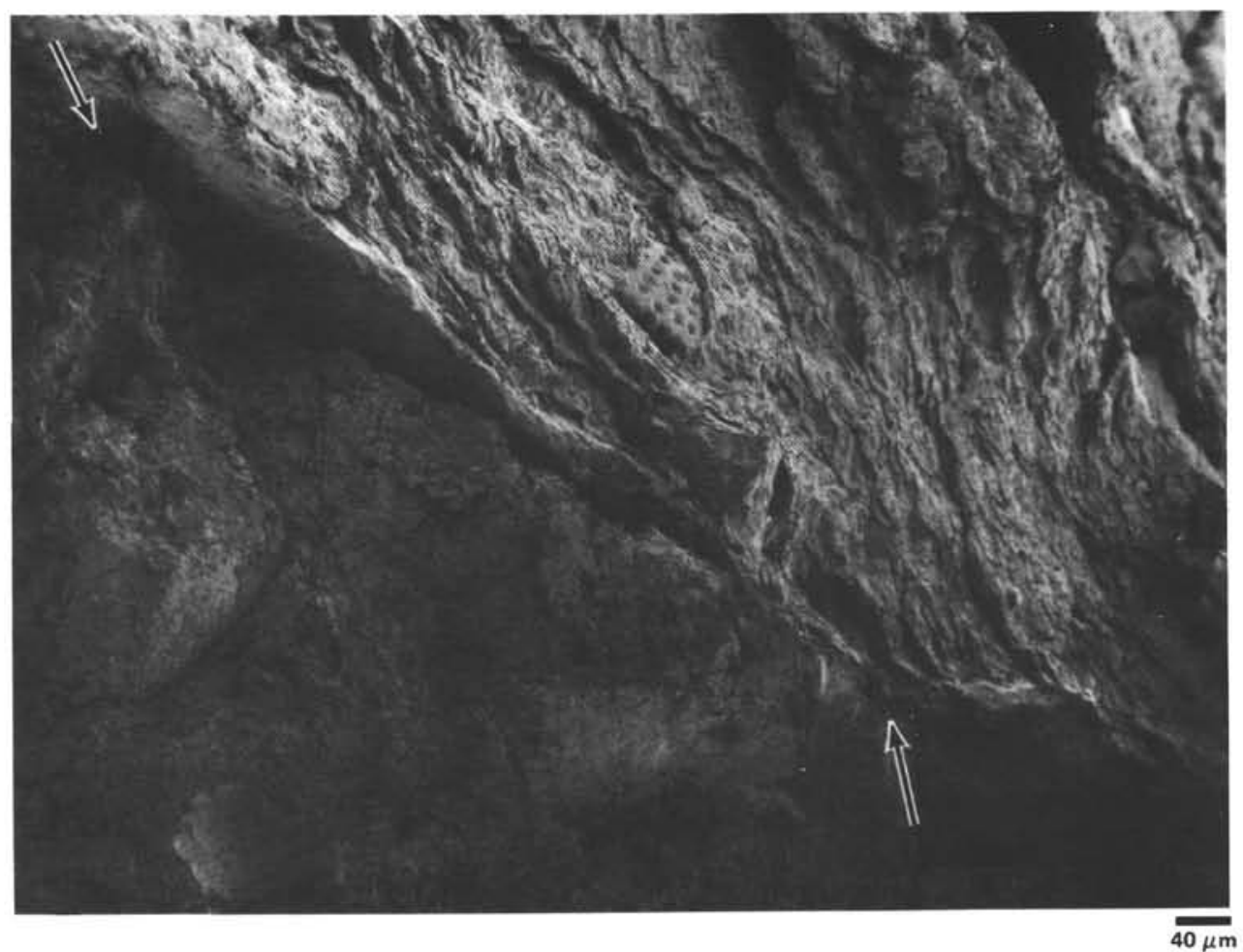

Figure 6. SEM photomicrograph of fault in Core 541-30, Section 6 (276 m sub-bottom depth). (Arrows denote position of fault. Scaly Miocene mudstone above fault includes remanent of broken foraminifer test. Note strong foliation in scaly mudstone above fault and absence of similar fabric in Pliocene calcareous mud below fault.)

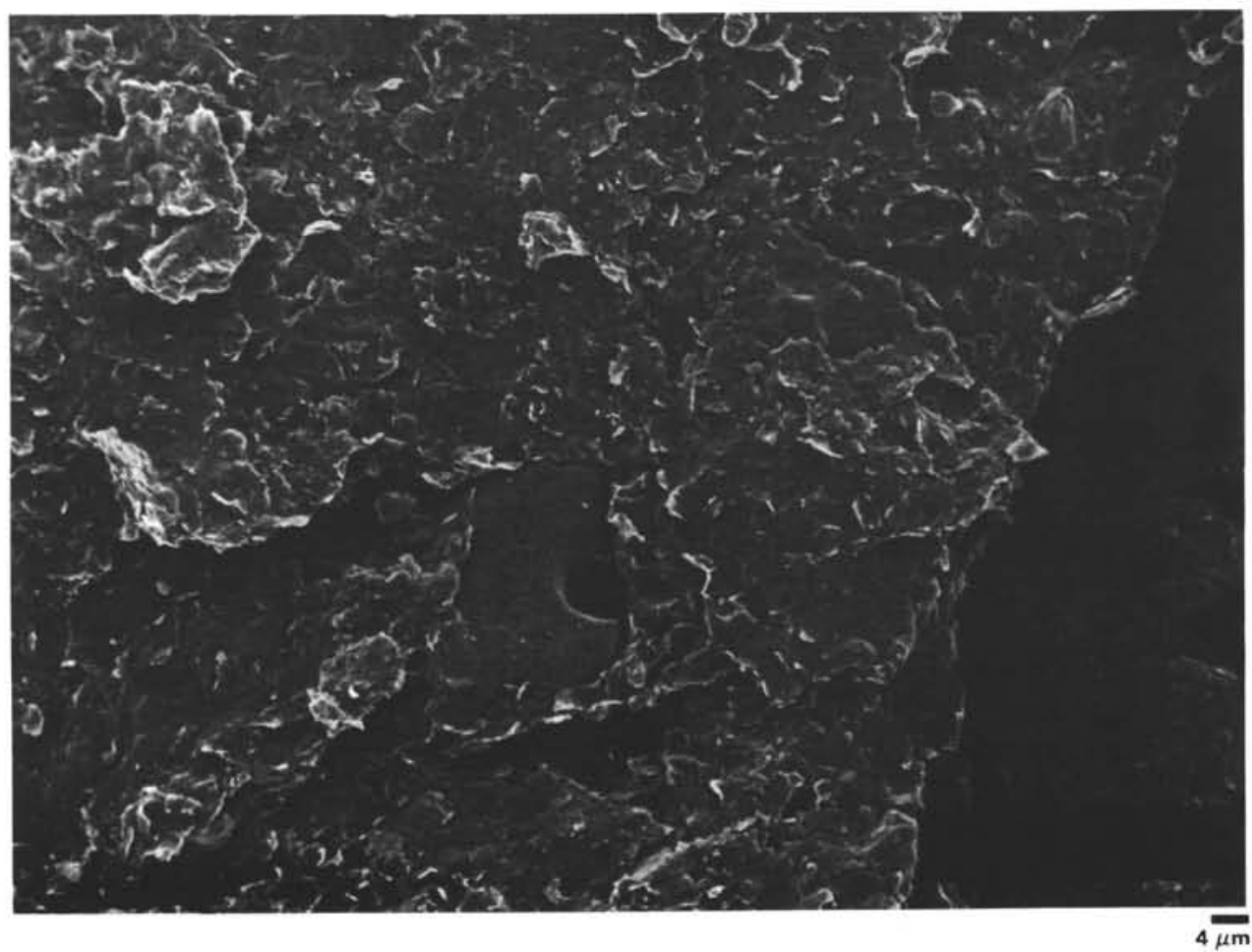

Figure 7. SEM photomicrograph perpendicular to foliation surface of Miocene hemipelagic mud within 5 $\mathrm{mm}$ from the fault in Core 541-30, Section 6 (276 m sub-bottom depth). (Note flattening of clays in foliation surface and piece of broken foraminifer test.) 
A

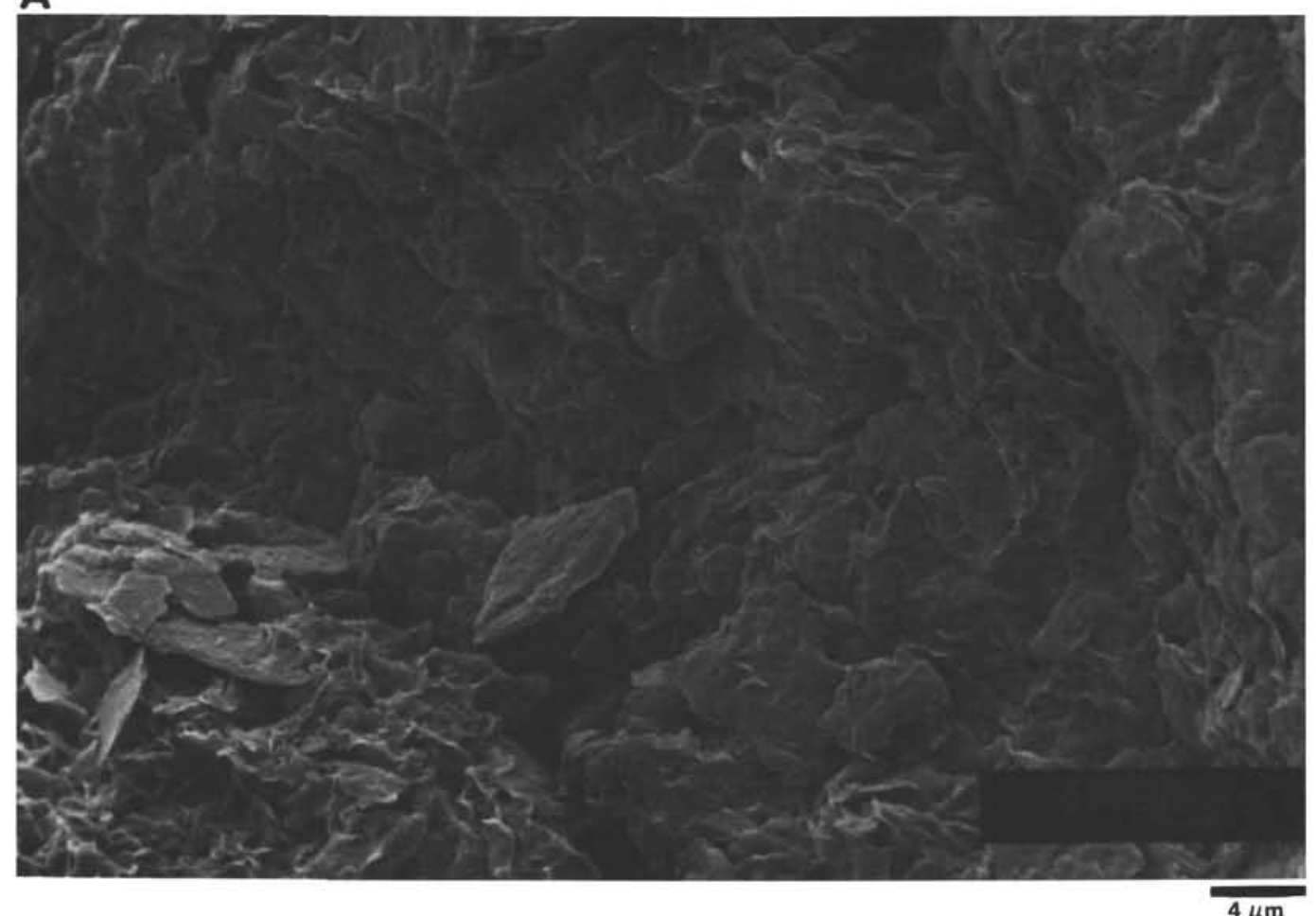

B

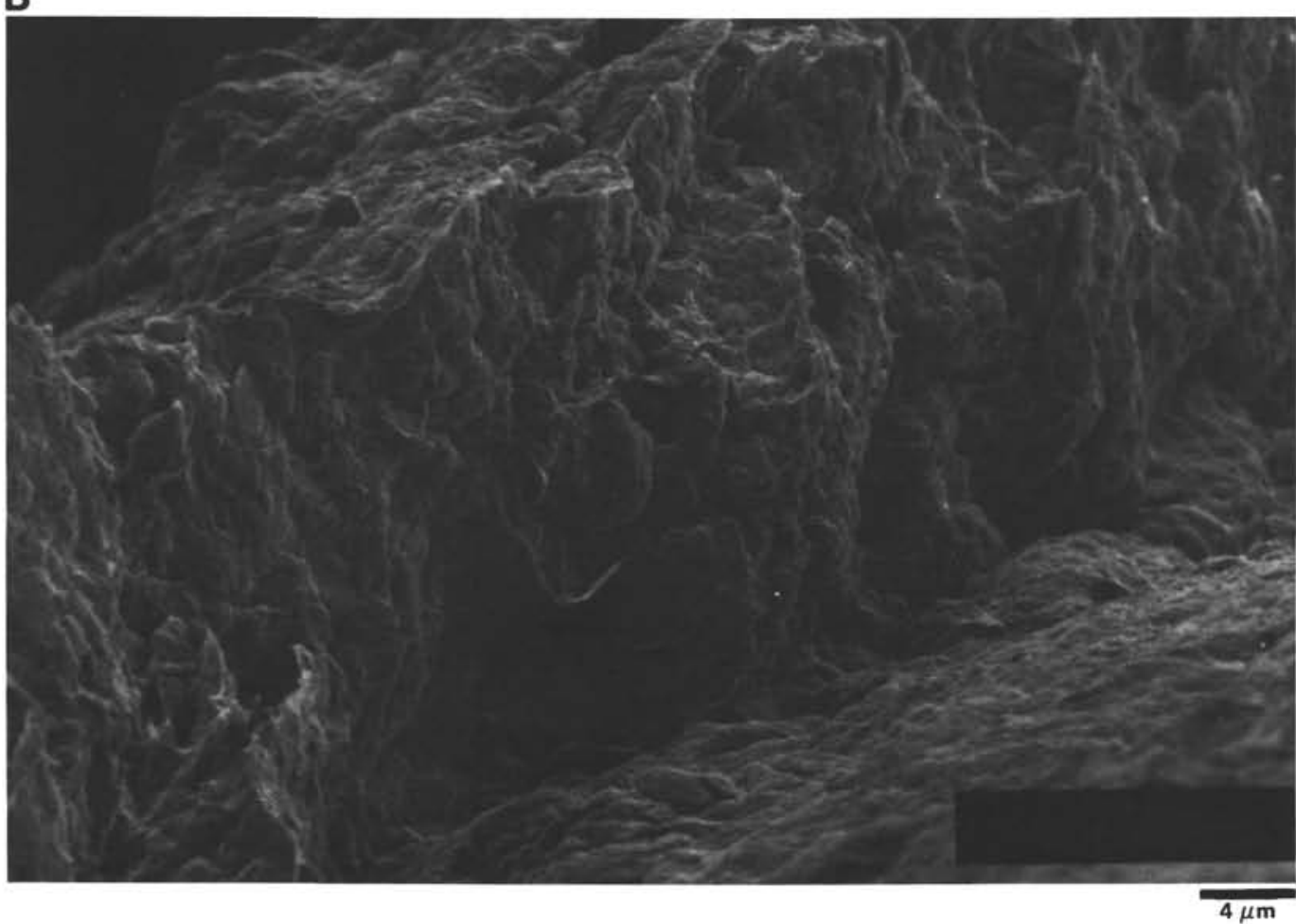

Figure 8. A and B. SEM photomicrographs of undeformed Miocene hemipelagic mud from Core 14, Section 2, 78 $80 \mathrm{~cm}$ at Site 543, the ocean-floor reference hole. (Compare the weak fabric [probably related to compaction] to strong fabric at Site 541 [Figs. 6 and 7].) 


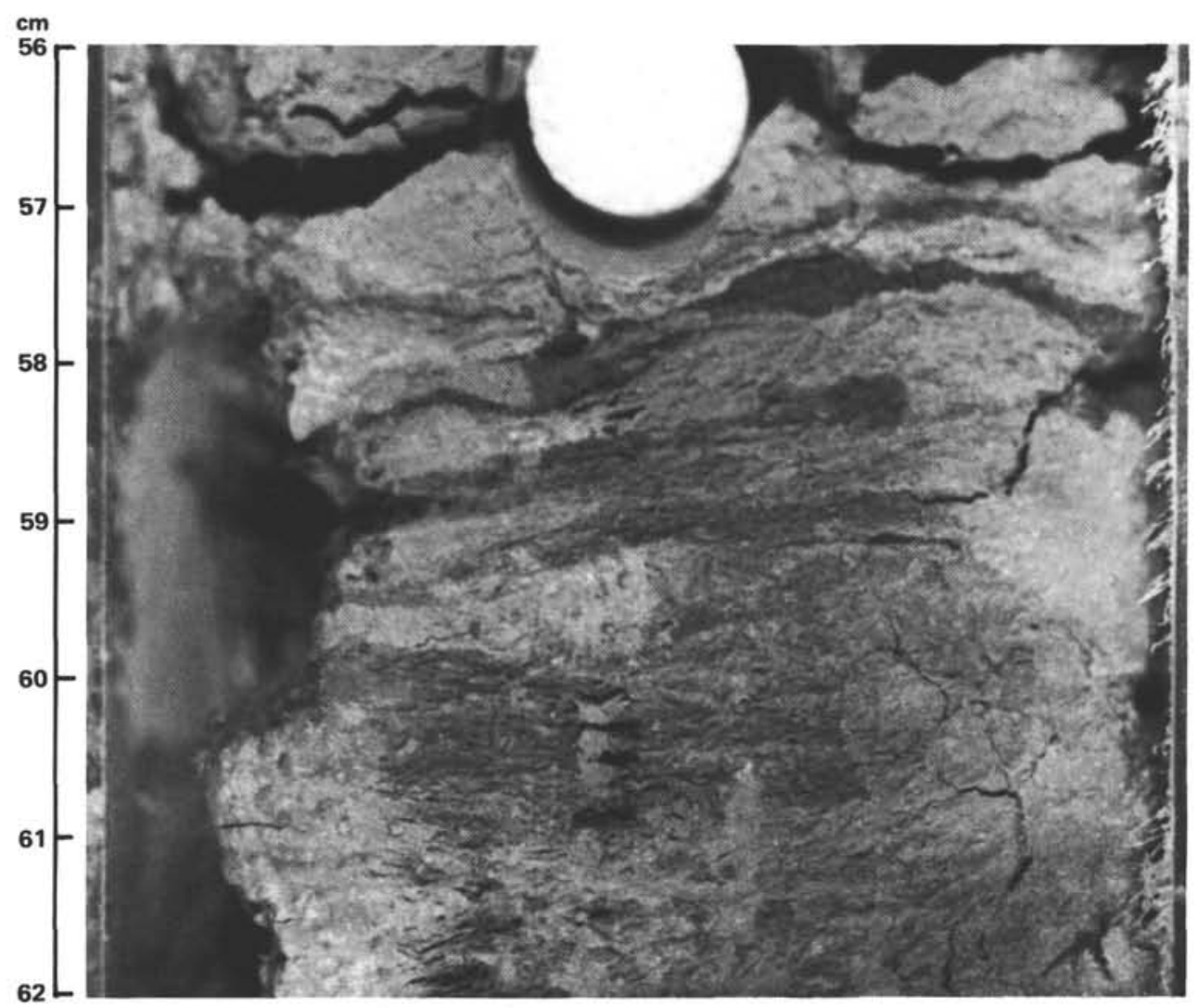

Figure 9. Sample 541-50-3, 56-62 cm. (Scaly foliation in soft, flaky mudstone is oriented approximately normally to the core axis [i.e., horizontal in situ]. This fabric is apparently the result of faulting within a broad zone of décollement.)

fossiliferous mudstone within the décollement zone. Control samples of pelagic mud from broadly the same stratigraphic interval at Site 543, the oceanic reference site, contain well-preserved, delicate radiolarian tests and fragments (Fig. 12A and B). In contrast, fragments of radiolarians in mudstone from the shear zone appear to have shattered in place (Fig. 13). Several samples examined with the SEM are devoid of the complete, delicate tests that are so abundant in undeformed and unfoliated pelagic muds from the oceanic reference section.

\section{SITE 542}

The sequence penetrated in Holes 542 and 542A includes stratigraphic repetitions indicative of thrust or reverse faulting. A $32-\mathrm{m}$ section is repeated between Holes 542 and $542 \mathrm{~A}$ along a fault or faults in an uncored section between 183 and $202 \mathrm{~m}$ sub-bottom (Bergen, this volume). From 240 to $325 \mathrm{~m}$ (bottom of Hole $542 \mathrm{~A}$ ), cores include intermittent nannofossil assemblages all assignable to a single zone (CN9a). Repetitions of certain nannofossil groups suggest several stratigraphic inversions in this sequence (Bergen, this volume). Comparisons of the anomalous thickness of this zone with that of zones having comparable duration and sediment type at Site 543 suggest a total stratigraphic repetition of about $70 \mathrm{~m}$. Overall the age and lithology of the sediments at the base of Hole 542A suggest it did not penetrate through the décollement zone as did Hole
541. Rather, the basal deformation zone at Site 542 probably is a major zone of thrust or reverse faulting lying just above the décollement.

In the two holes drilled at this site, 542 and $542 \mathrm{~A}$, measurable bedding dips range from $1^{\circ}$ to $30^{\circ}$ and average $13^{\circ}$ (Fig. 2). Undisturbed bedding was rarely observed below about $260 \mathrm{~m}$ sub-bottom. Much of the section below Core 542A-3 (249.5 m) (in the zone of multiple stratigraphic repetitions) displays semipenetrative, diversely oriented polished surfaces spaced $1 \mathrm{~mm}$ to 1 $\mathrm{cm}$ apart. This fabric, also present in Cores 25 to 30 at Site 541, comprises small-scale slip surfaces along which mesoscopically ductile flow was accommodated. Other indications of internal flow of coherent but pliant mud are (1) stretched, distorted burrows and mottles (especially in Sections 5 and 6 of Core 542A-6 and Sections 4 and 5 of Core $542 \mathrm{~A}-8$ ) and (2) distorted bands of differently colored mud represently disrupted sedimentary layers. Other evidence for faulting may include the poor recovery, general deterioration in hole conditions, and common drill-induced deformation in Core 542A-7 and below. The inadvertent packer experiment (see Site 542 report) points to high in situ fluid pressures in this thrust zone.

\section{VEIN STRUCTURE}

A small-scale structure, variously termed "vein structure" or "veins," has been noted in DSDP cores ob- 


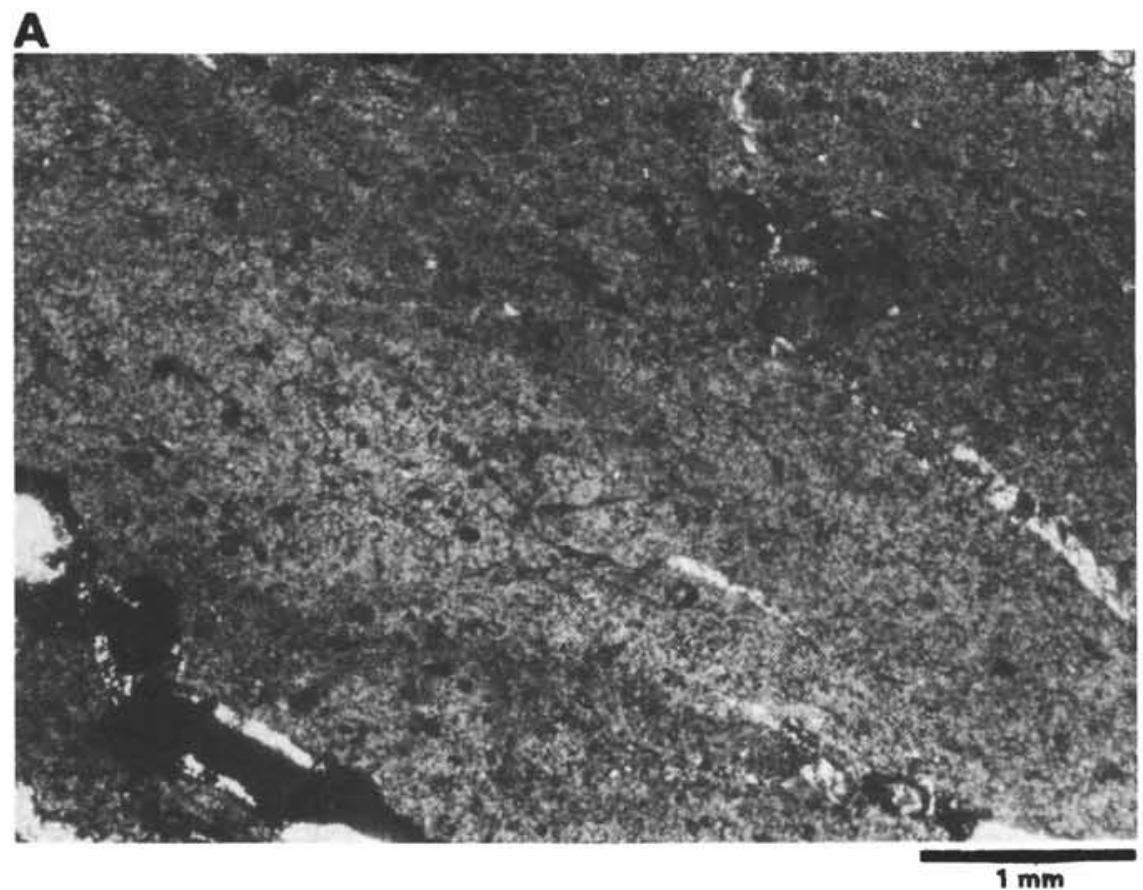

B

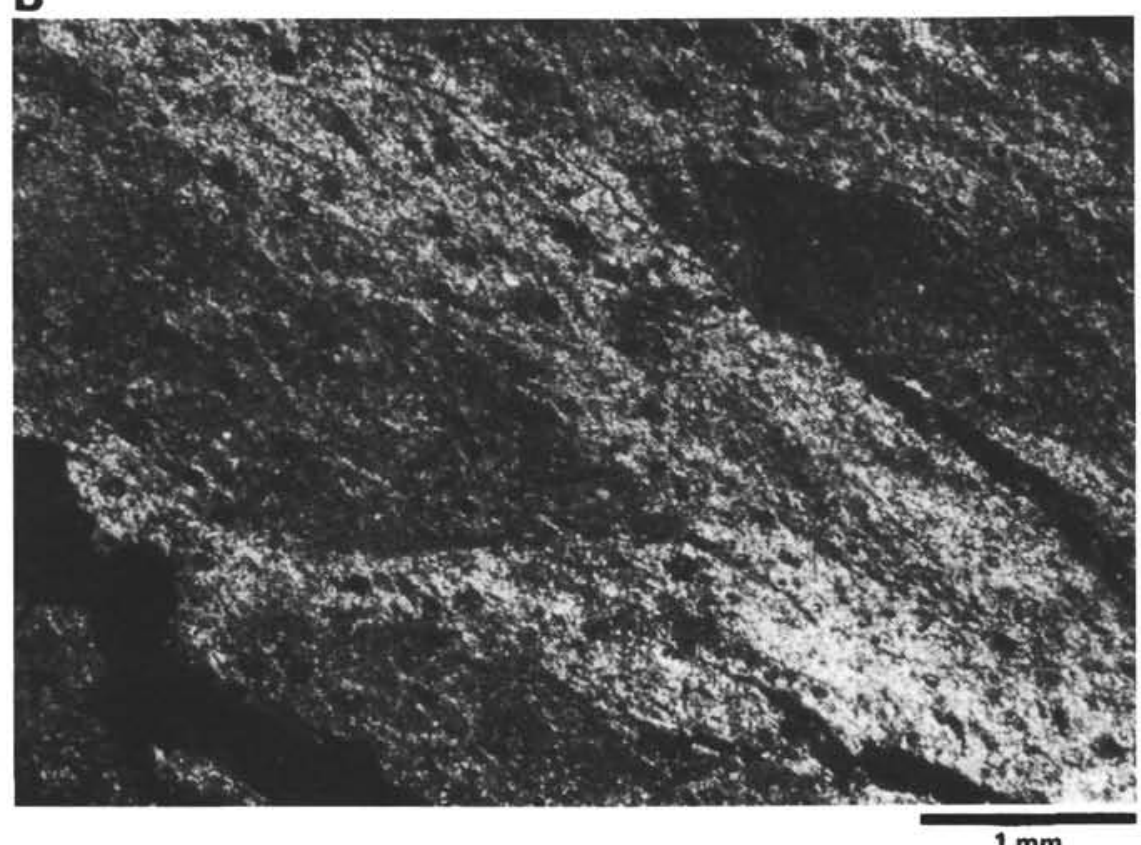

$1 \mathrm{~mm}$

Figure 10. Photomicrographs of thin section of foliated, scaly mudstone from the décollement zone at Site 541, Core 50, Section 3,58-62 cm. A. In plane light, zones of slightly differently colored mudstone are arranged subparallel to the foliation. B. Under crossed nicols, phyllosilicates are strongly oriented (bright when viewed at $45^{\circ}$ off extinction) in anastomosing zones enclosing lenticular domains of less strongly oriented clays.

tained from the forearc region at several active convergent plate boundaries (Japan Trench, Legs 56 and 57Arthur et al., 1980. Middle America Trench: Leg 66Lundberg and Moore, 1981; Leg 67-Cowan, 1982; Leg 84-Y. Ogawa, personal communication, 1982). In Hole 541 , Cores 19, 40,42, and 45, and in Hole 542A, Cores 1 and 8 , this structure was weakly developed (identified as pseudoveins in Fig. 2). Veins in these cores are dark,
1- to 2-mm-thick, horizontal or vertical planar to curviplanar discontinuities spaced about 1 to $50 \mathrm{~mm}$ apart. They appear on cut surfaces of cores as subparallel lines or narrow zones or are arranged in an anastomosing pattern, and they are separated from one another by normal mud. Subparallel veins divide the mud into thin, approximately planar panels (e.g., Cowan, 1982), but some veins at Site 541 anastomose around a common 


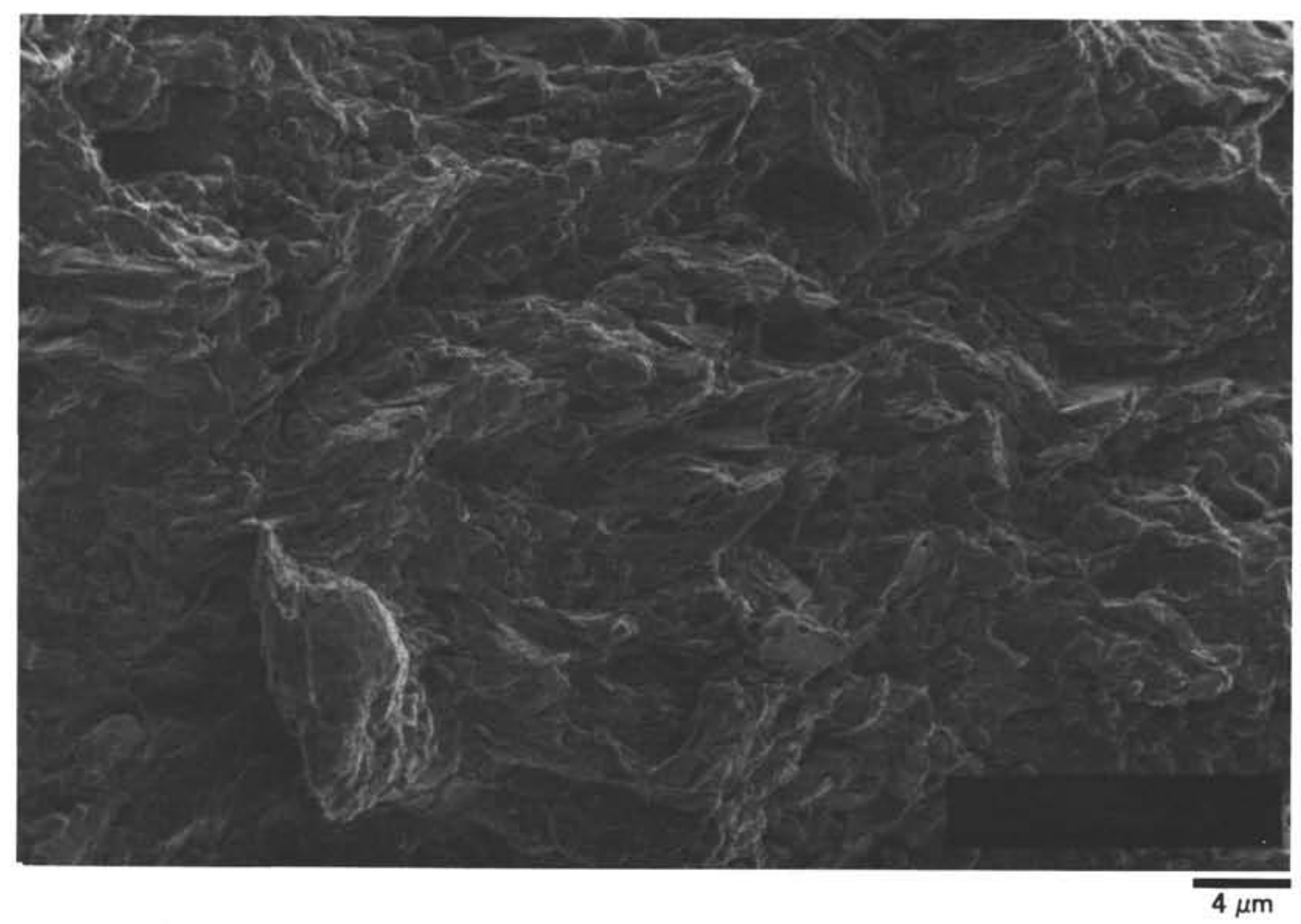

Figure 11. SEM photomicrograph of clay-rich lower Miocene radiolarian mud from décollement zone-Sample 541$50-3,51-55 \mathrm{~cm}$. (Photomicrograph illustrates moderate preferred orientation of platy minerals due to penetrative microscopic slip.)

"zone axis" and segment the mud into roughly cylindrical rods about 1 to $3 \mathrm{~mm}$ in diameter. Thin sections show that phyllosilicates within veins are strongly oriented parallel to vein boundaries (Fig. 14). The origin of vein structure in general is not yet understood, although Arthur et al. (1980) and Cowan (1982) interpret it as a dewatering structure developed in a nonhydrostatic stress field.

\section{SUMMARY}

Cores from Sites 541 and 542 provide examples of structures associated with faults at the deformation front of a major accretionary prism. The thrust faults penetrated are marked by biostratigraphic changes that prove repetition of section. Displacements along these faults were probably accompanied by semipenetrative displacements along minor slip surfaces. Deformation in the pliant, partially consolildated muds was locally intense enough to have resulted in stratal distortion and disruption and, adjacent to the faults, scaly foliation. The lack of penetrative mesoscopic or microscopic deformation in Pliocene calcareous mud below the fault at $276 \mathrm{~m}$ at Site 541 indicates that the mineralogy of mud may influence its response to deformation. It is important to note that, aside from the décollement zone and individual thrust, beds in situ are generally well-preserved, apparently upright, and horizontally to gently dipping. The off-scraped deposits above the décollement zone are not chaotically churned, thoroughly disrupted melange, even though, on seismic reflection pro- files, the toe of the accretionary wedge is acoustically transparent and lacks well-defined landward-dipping reflectors.

Layer-parallel displacements along a major décollement, penetrated in the lower reaches of the hole at Site 541 , imparted a scaly foliation to hemipelagic and pelagic muds. Strata were locally disrupted into inclusions enclosed in the scaly, foliated mudstone, although there are no strong lithologic contrasts in the deformed section and, consequently, no "block-in-matrix" chaotic fabric. The alteration of fractured, scaly mud with intervals of undisrupted sediments suggests that the onset of deformation is progressive. Drilling evidence indicates that the seismically defined décollement is a wide zone, at least $75 \mathrm{~m}$ thick, in which high fluid pressures facilitated the subduction of ocean-floor sediments beneath an imbricated accretionary wedge.

\section{ACKNOWLEDGMENTS}

We gratefully acknowledge National Science Foundation Grant OCE 81-10394, which supported S. Roeske's scanning electron microscopy and N. Lundberg's reexamination of the cores. We also thank our fellow shipboard scientists for discussions on all aspects of the structure of sites drilled during Leg 78A. Ed Beutner provided a useful review of an earlier draft of this chapter.

\section{REFERENCES}

Arthur, M. A., Carson, B., and von Huene, R., 1980. Initial tectonic deformation of hemipelagic sediment at the leading edge of the Japan convergent margin. In Scientific Party, Init. Repts. DSDP, 56, 57, Pt. 1: Washington (U.S. Govt. Printing Office), 569-613. 
Cowan, D. S., 1982. Origin of "vein structure" in slope sediments on the inner slope of the Middle America Trench off Guatemala. InAubouin, J., von Huene, R., et al., Init. Repts. DSDP, 67: Washington (U.S. Govt. Printing Office), 645-650.

Karig, D. E., 1974. Evolution of arc systems in the western Pacific. Ann. Rev. Earth Planet. Sci., 2:51-75.

Lundberg, N., and Moore, J. C., 1981. Structural features of the Middle America Trench slope off Southern Mexico, DSDP Leg 66. In
Watkins, J. S., Moore, J. C., et al., Init. Repts. DSDP, 66: Washington (U.S. Govt. Printing Office), 793-814.

Seely, D. R., Vail, P. R., and Walton, G. G., 1974. Trench slope model. In Burk, C. A., and Drake, C. L. (eds.), The Geology of Continental Margins: New York (Springer-Verlag), pp. 249-260.

Date of Initial Receipt: January 3, 1983 Date of Acceptance: July 6, 1983 
A

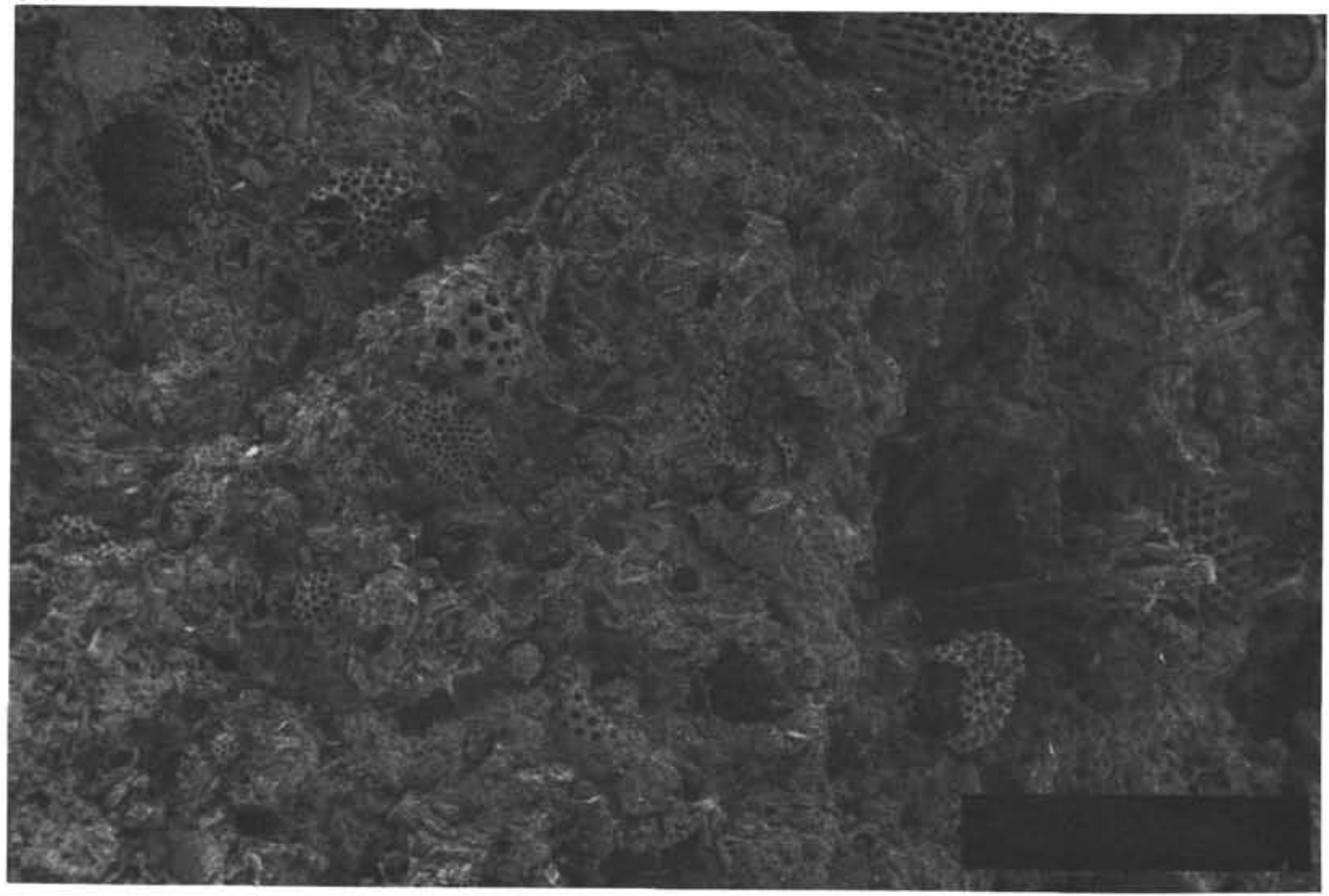

B

$40 \mu \mathrm{m}$

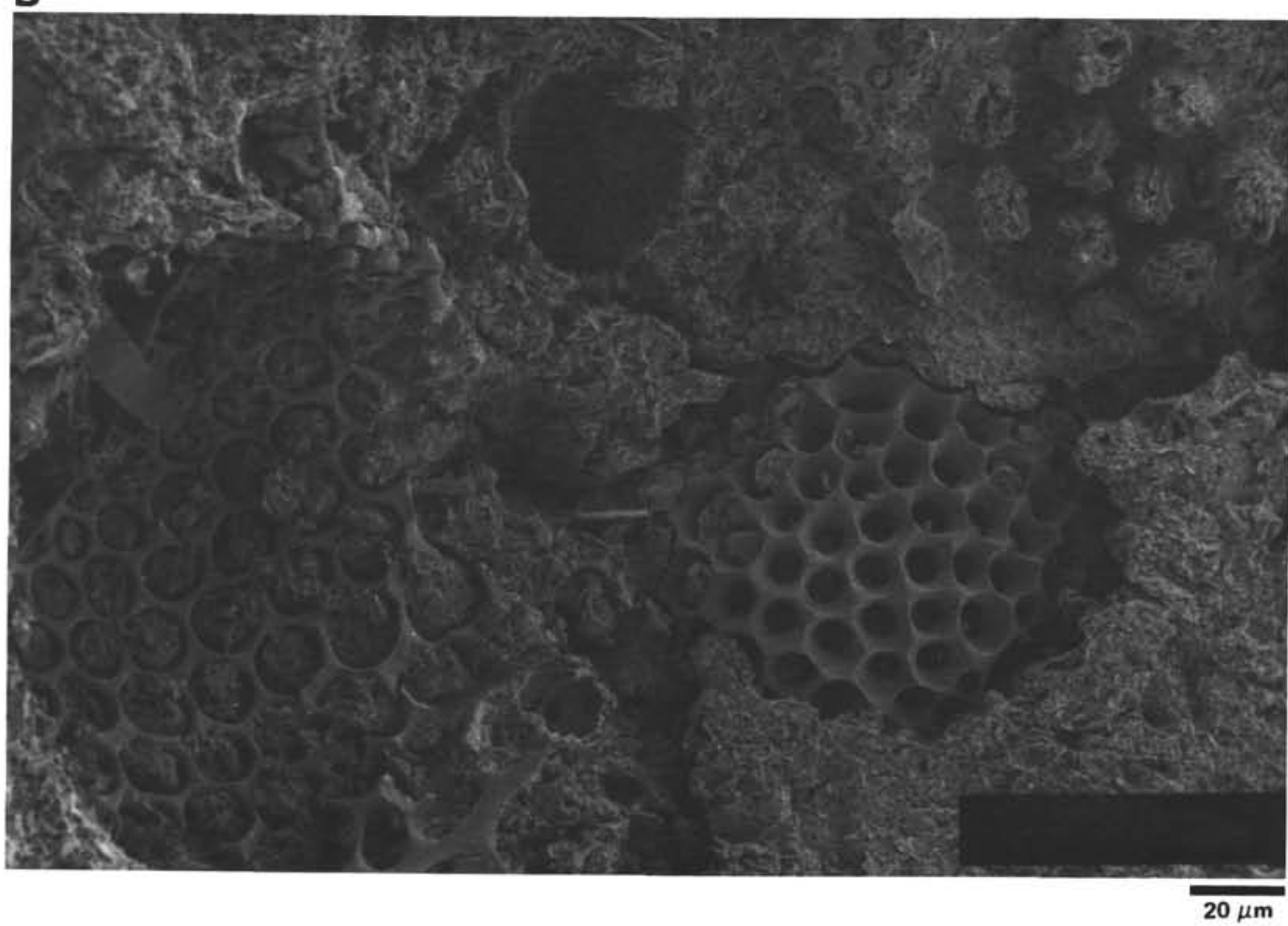

Figure 12. A and B. SEM photomicrographs of undeformed radiolarian mud from ocean-floor reference Hole 543, Core 18, Section 4. (Note well-preserved tests in comparison to samples from the décollement zone at Site 541, illustrated in Fig. 13.) 
A

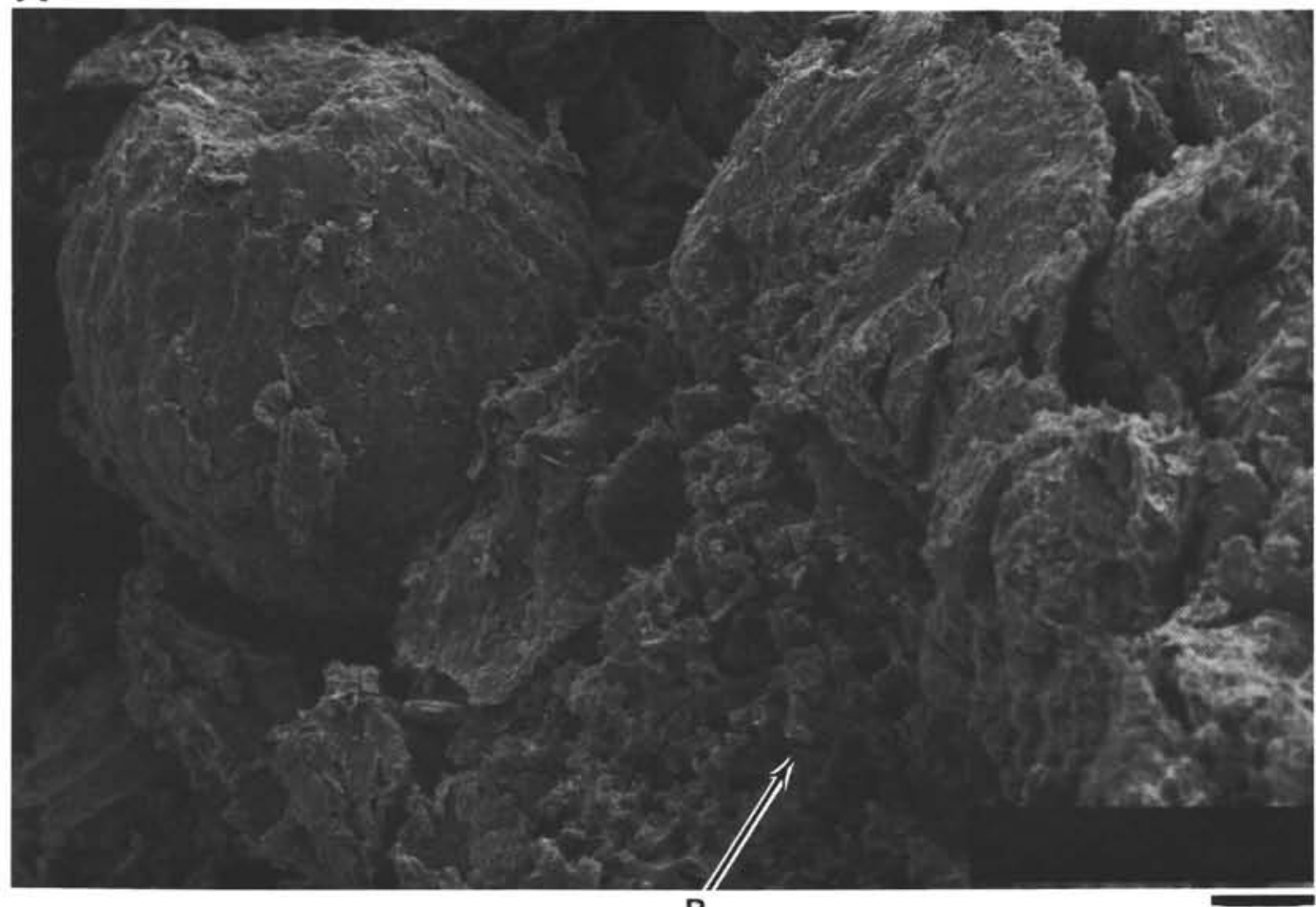

$\mathbf{B}$

R

$20 \mu \mathrm{m}$

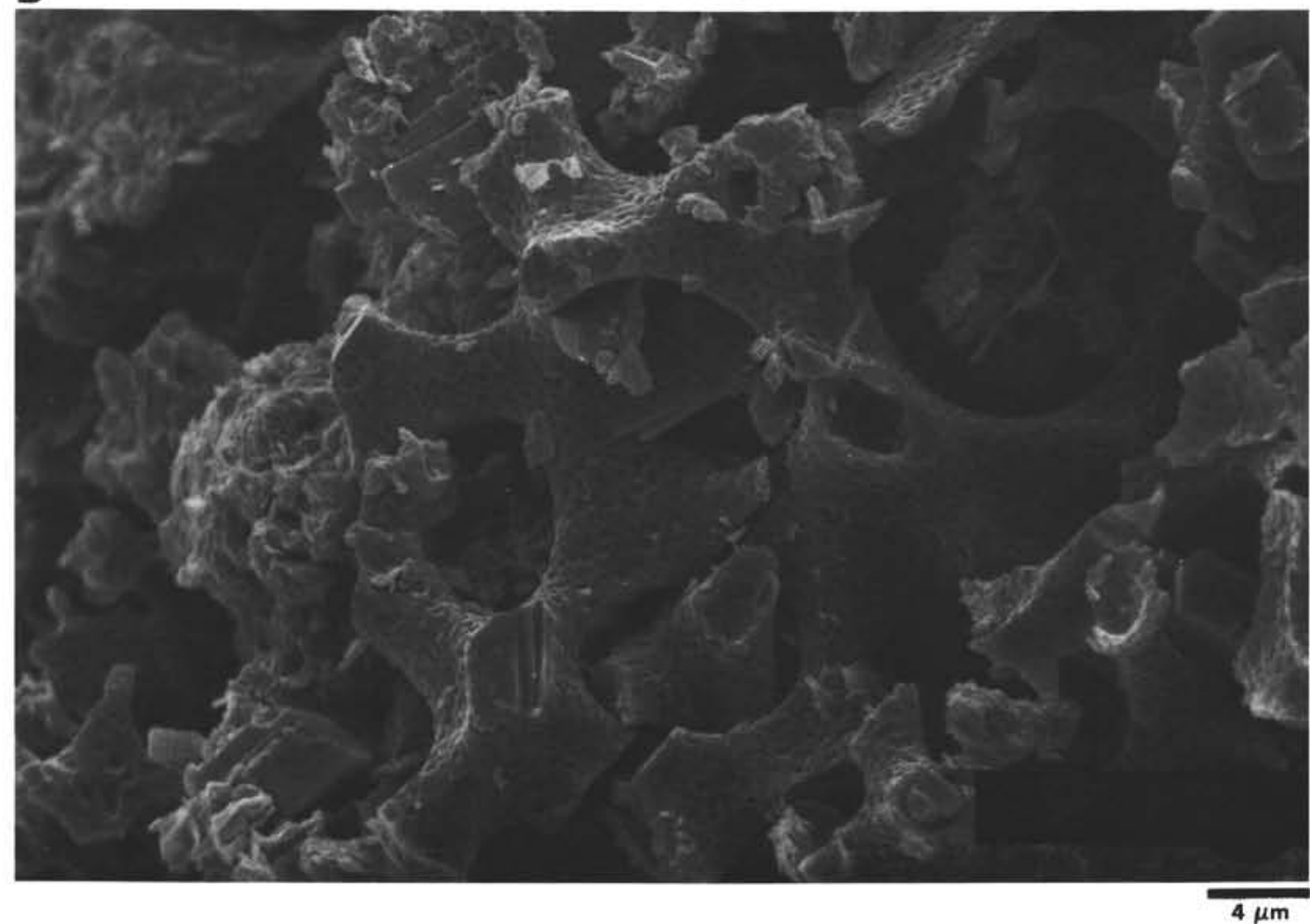

Figure 13. SEM photomicrographs of foliated radiolarian mudstone from décollement zone at Site 541, Core 50, Section 3. A. Radiolarian tests have fractured in place (note imploded test marked with R) and are in general much less complete than in the undeformed mudstone at Site 543 (Fig. 12). B. Enlargement of part of the field in Fig. 13A. (Note authigenic mineral growth.) 
D. S. COWAN ET AL.

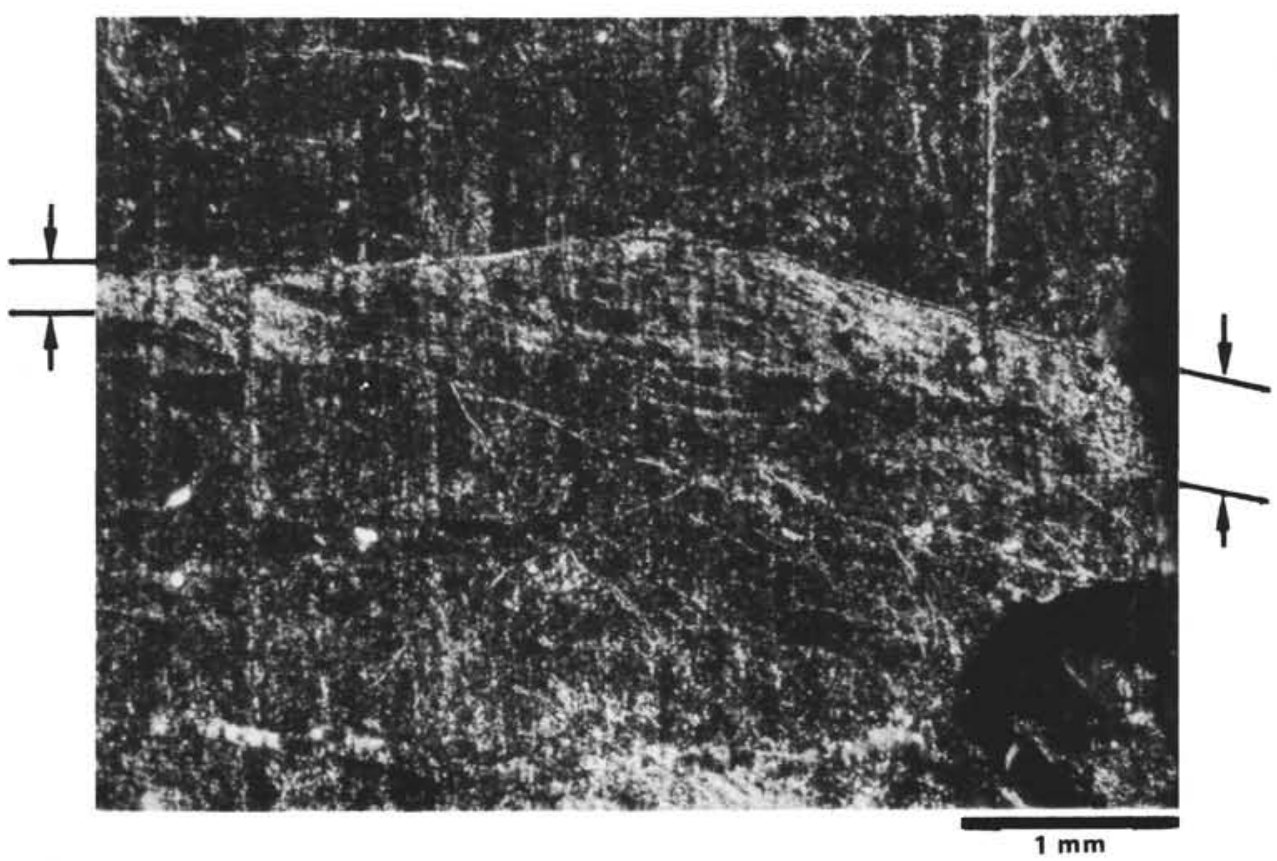

Figure 14. Thin section, photographed under crossed nicols, of "vein structure" from Sample 541-45-3, $130 \mathrm{~cm}$. (Phyllosilicates are strongly oriented subparallel to the boundaries of the vein, which are denoted by arrows. Vertically oriented streaks are striations resulting from grinding during preparation of the thin section.) 